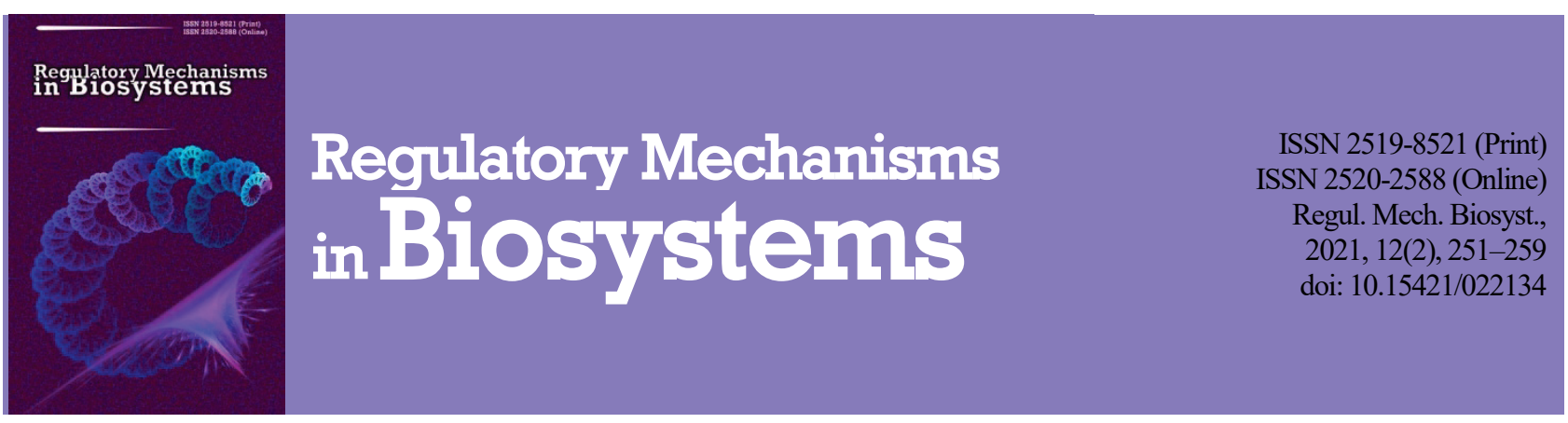

\title{
Current issues and gaps in the implementation of rabies prevention in Ukraine in recent decades
}

\author{
I. F. Makovska*, T. M. Krupinina**, V. V. Nedosekov*, T. M. Tsarenko***, Y. A. Novohatniy****, A. S. Fahrion ***** \\ *National University of Life and Environmental Sciences of Ukraine, Kyiv, Ukraine \\ **Poltava Oblast Center for Diseases Control and Prevention of the Ministry of Health of Ukraine, Poltava, Ukraine \\ ***Bila Tserkva National Agrarian University, Bila Tserkva, Ukraine \\ ****Oblast Center for Diseases Control and Prevention of the Ministry of Health, Kyiv, Ukraine \\ *****Friedrich-Loeffler-Institut, Greifswald-Insel Riems, Germany
}

Article info

Received 16.03.2021

Received in revised form 25.04.2021

Accepted 28.04.2021

National University of Life and Environmental Sciences of Ukraine, Heroiv Oborony st., 15 , building 3, Kyiv, 03041, Ukraine. Tel:+38-093-833-19-77

E-mail: rryna.makovska@ubip.edu.ua

Poltava Oblast Center for Diseases Control and Prevention of the Ministry of Health of Ukraine, Vatutina st., 35a, Poltava, 36039, Ukraine. Tel: +38-067-799-96-85.

E-mail:krupinina@ukr.net

Bila Tserkva National Agrarian University, Soborna st., 8/1, Bila Tserkva, 09117, Ukraine. Tel.:+38-068-353-63-69.

E-mail:taras.m.tsarenko@gmail.com

Oblast Center for Diseases Control and Prevention of the Ministry of Health Herzen st., 31, Kyiv, 04050, Ukraine Tel.: +38-073-406-60-42.

E-mail:y.nov.oni@ukr.net

Friedrich-Loefler-Institut, Federal Research Institute for Animal Health, Südufer 10 Greifswald-Insel Riems, 17493, Germany. Tel.:+49-038-351-70. E-mail: anna.fahrion@fli.de

\section{Introduction}

Rabies is a fatal viral disease that can be prevented by a vaccine (Fooks et al., 2017, World Health Organization, 2018). Rabies is transmitted to humans through contact with sick animals whose saliva contains the virus. The main carriers of rabies for humans are unvaccinated domestic carnivores that can get rabies (Rupprecht \& Salahuddin, 2019; Klein et al., 2020). Many countries have managed to get rid of rabies, the agent of which is transmitted mainly through dog bites, or to significantly improve the endemic situation (Franka \& Wallace, 2018; Meyerhoff et al., 2021). This success has been achieved primarily by the use of effective policies and programmes that focus on campaigns for vaccination of dogs, public awareness-raising, widespread use and availability of post-exposure prophylaxis (PEP) (Calvelage et al., 2020; Meyerhoff et al., 2021). Although mass vaccination of dogs is expected to be an important part of any effective strategy, the most important issue in preventing human rabies is the vaccination of people living in rabies-endemic countries before and after
Makovska, I. F., Krupinina, T. M., Nedosekov, V. V., Tsarenko, T. M., Novohatniy, Y. A., \& Fahrion, A. S. (2021). Current issues and gaps in the implementation of rabies prevention in Ukraine in recent decades. Regulatory Me-

Ukraine remains the only country in Europe where rabies is widespread among animals and humans. Annually there are about 1,600 rabies cases in animals in Ukraine and sporadic cases in humans have been registered despite the conducting of preventive measures. Therefore, the aim of the study was to inspect the failures in rabies prevention, indidistribution in Ukraine during 1996-2020. The following archival state materials were used for analysis: from the MinisSafety and Consumer Protection. In general, more than 84,000 people ( 187.4 per 100,000 of the population) were afPost-exposure prophylaxis (PEP) was prescribed annually, on average, for 21,434 patients (25.5\% of all victims). Most rabid dogs on humans was (1:124), from cats (1:25), wild animals (1:7), and farm animals (1:2), but the largest general evel contact with people, attacks by dogs remains more dangerous. Geographically attacks on humans by domestic high density of the human population. A large number of attacks by foxes was observed in the west part of Ukraine due to the larger area of forests and fields. During the last 25 years, there have been 63 human rabies cases. The main sources of rabies were dogs ( 24 cases) and cats (22 cases). The main causes of development of rabies were: failure to receive the PEP due to the absence of a visit to a hospital after an attack of an animal $(n=38)$, failures in prescribing PEP $(n=15)$, sectoral links, the lack of significant efforts to raise public awareness and the lack of funding for prophylaxis programmes for humans and animals. Our future research will be aimed at modelling the transmission of rabies from the

Keywords: epidemiology of rabies; rabid animals; dog bites; rabies exposure; rabies vaccines; spatial distribution.

exposure (Baghi et al., 2019; Brookes et al., 2019; Gholami \& Alamdary, 2020). In addition, human rabies occurs more than in 150 countries and territories (Fooks et al., 2017; Fisher et al., 2018). Dog rabies produces around 59,000 human deaths, more than 3.7 million people with disability adjustments and $\$ 8.6$ billion of economic damages every year around the globe (Shwiff et al., 2013; Robardet et al., 2019; Yoder et al., 2019). As reported by Hampson et al. (2015), the biggest component of the economic burden relates to premature death $(55.0 \%)$, under which direct expenses for prevention measures (PEP, 20.0\%) and medicines are included in the PEP (15.5\%), with limited costs for vaccination of animals $(1.5 \%)$ and extra expenses associated with livestock loss $(6.0 \%)$. Besides this, all consequences also combine losses correlated with the risk of human fatality, which leads to total economic damages caused by canine rabies of \$ 120 billion (Regea, 2017; Anderson et al., 2019). In Ukraine, the prescribed course of anti-rabies vaccinations costs about $\$ 215$ per human, depending on the severity of the bite. In general economic costs of treating rabies are enormous: the cost of the vaccine consumed annually 
for humans is about $\$ 1$ million, excluding rabies immunoglobulin used for the combined course of vaccinations (Antonova et al., 2021). In addition, about \$ 3 million during the last 10 years in Ukraine were lost due to livestock rabies, while there are also considerable losses from funding vaccination campaigns for wild and domestic carnivores which unfortunately were ineffective (Kornienko et al., 2019; Taylor et al., 2021).

During the last few decades, more than 100,000 people (almost 210 per 100,000 population) turned to medical institutions for treatment of animal bites annually. Every year, up to 23,000 people have been prescribed rabies vaccinations (Kornienko et al., 2019; Polupan et al., 2021). Historically, before 1970, dogs were a common reservoir and sources of rabies in Ukraine, however, due to the increasing population of wildlife, the main reservoir and source of rabies in Ukraine became red foxes (Vulpes vulpes) (Botvinkin \& Kosenko, 2004; Baker et al., 2020). As reported by Makovska et al. (2020) from 2000 to 2019 foxes accounted for $88.3 \%$ of wildlife rabies cases and $36.5 \%$ of general rabies cases. Besides these, domestic carnivores (including strays) were additional sources of rabies. Cats accounted for $25.5 \%$ and dogs for $19.3 \%$. The last high peak of the incidence of rabies in animals was recorded in 2007 with the number of laboratory confirmed cases 2,932 . Since 2007 the number of rabies cases among domesticated companion animals has increased and in 2016 the number of rabies cases in cats was higher than in foxes (Drozhzhe, 2015; Makovska et al., 2018; Kornienko et al., 2019).

The difficult epizootic situation with rabies in animals poses a permanent threat of complicating the epidemic situation in Ukraine. Based on the results of epizootiological laboratory monitoring, there has been a pronounced tendency with respect to human rabies infections: reduction of manifestations of rabies among foxes and an increase among cats and dogs. Thus, during 1997-2017, cats were the source of rabies for humans in $39.6 \%$ of cases, dogs - in $29.3 \%$ and foxes - only in $20.7 \%$, others $8.7 \%$, bats $-1.7 \%$. The most meaningful factors of the increasing role of domestic carnivores as a source of rabies for humans are low levels of specific rabies prevention in domestic animals and the increased density of the population of stray dogs and cats (Polupan et al., 2021). Among the most important preventive measures which need to covered by monitorring are problems of irresponsible pet ownership, stray dogs and cats, the possibility of full immune prophylaxis of rabies (both in humans and animals). Lack of reliable information is one of the main obstacles to effective prevention and control of human rabies, not only at the global but also at the national level (Grigoryan \& Metlin, 2016; Acharya et al., 2020).

In this respect, the aim of our study is to indicate the problems, gaps and failures in rabies prevention, investigation of the main reasons for human rabies cases and highlighting the risk of animal attacks in view of their species and geographical distribution on all territory of Ukraine during 1996-2020.

\section{Materials and methods}

In Ukraine, the function of the implementation of epidemiological surveillance of rabies is entrusted to 24 oblast laboratory centres of the Ministry of Health of Ukraine. The post-exposure prophylaxis prescription takes place at 726 units and 22 centres of rabies assistance (points of PEP) operating under traumatological or surgical units of health facilities of the Ministry of Health at rayon or oblast levels. First aid to those affected by animals is provided at any health facility with further referral to the PEP unit. Constant components of monitoring include recording the number of cases when patients refer to healthcare facilities with injuries resulting from animal attacks or from other dangerous contacts with animals. The number of cases is recorded by the species of animals that attacked people. Information about post-exposure prophylaxis is taken into account too. Monthly official statistical reports on cases of infectious diseases in humans and animals are prepared. There is constant monitorring of indicators of surveillance and exchange of information between the Ministry of Health of Ukraine facilities and veterinary medicine facilities regarding the epidemic and epizootic situation of rabies, the cases of animal attacks on people and the results of diagnosis of rabies in these and other animals, the need for and results of quarantine of attacking animals, PEP scope and other preventive measures. Monitoring involves the constant exchange of information between different institutions. The relation- ship between institutions that implement epidemiological surveillance, medical care, and veterinary medicine is particularly close.

Consolidated data from various sources were used to analyze problems and gaps in knowledge about rabies. Sources of primary data were the following archival materials about human rabies cases reported in Ukraine from 1996 to 2020; state statistical reporting from national reports of infectious diseases in humans, information from epidemiologists' reports about investigations of human rabies cases and monitoring data for rabies surveillance from the Ministry of Health of Ukraine. Information about the human population was obtained from the State Statistics Service of Ukraine. The data regarding visits to health facilities by patients who suffered from animal attacks and the post-exposure prophylaxis scope were available from national monitoring tables (2007-2019) with indicators of epidemiological surveillance for rabies. Information on age, sex, localization of injuries, incubation period, laboratory confirmation was in some cases incomplete. Specific case descriptions were taken from the above analytical references, reports of cases of rabies, data of oblast level monitoring, scientific publications, personal experience. We also used available data about the animals, wild or domestic, if they had an owner, vaccination against rabies. The data included the number of attacks on people by rabid animals, as well as the number of cases of using postexposure prophylaxis and implementation of other preventive measures. The veterinary medicine oblast departments of the State Service of Ukraine for Food Safety and Consumer carried out epizootiology surveillance of rabies in Ukraine. Data on the epizootic situation were obtained from official annual reports of the oblast laboratories of veterinary medicine and oblast departments of the state veterinary service for the period from 2007 to 2019. Only laboratory-confirmed cases of animal rabies were recorded.

All mentioned data were aligned and consolidated by time and geographic affiliation for visualization and analysis of the problem of rabies in Ukraine. For spatial analysis free QGIS 3.4.6 (the USA, 2019) software were used. The choropleth maps were created using projection CRS: EPSG:102013 Europe Albers Equal Area Conic. Vector layers of Ukraine's borders and oblasts were obtained using free spatial data Diva-Gis (www.diva-gis.org/Data).

\section{Results}

In Ukraine, for the period 1996-2020, there were 63 cases of human deaths from rabies. Among these 63 fatal cases, there were 51 adults and 12 children (aged from 3 to17). In terms of spatial distribution, human rabies cases were observed in the majority of administrative oblasts of Ukraine (Fig. 1).

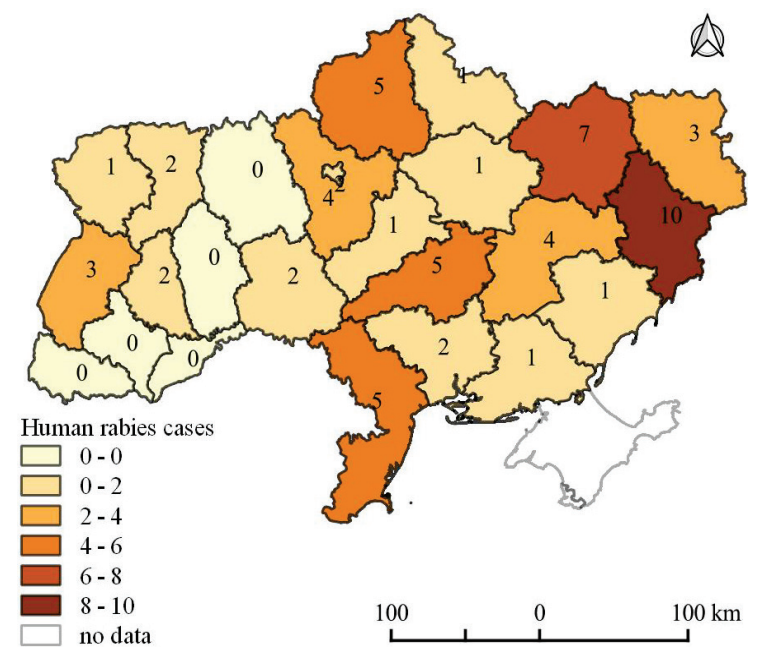

Fig. 1. Dispersion of rabies cases in humans per oblast during 1996-2020 according to the official statistical data of the Ministry of Health of Ukraine

Frequency of reported cases varied between 1 to 7 cases per year. The higher peaks were registered in 2007. There were no cases reported 
for 2012, however, one person infected in 2012 died after a 3-month incubation period, in 2013 (Fig. 2).

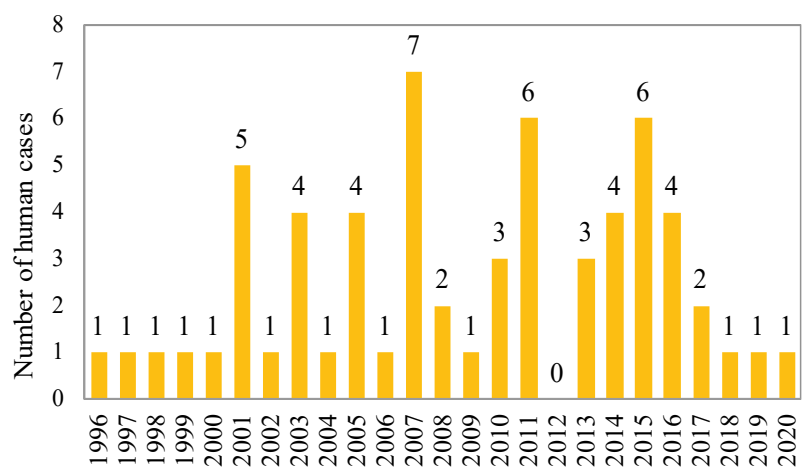

Fig. 2. The annual number of rabies cases in humans in Ukraine according to the official statistical data of the Ministry of Health of Ukraine (1996-2020)

In 62 out of 63 cases, there were typical clinical manifestations, and rabies was diagnosed intra vitam, based on anamnesis of animal bites and clinical signs and in the majority of cases (50) confirmed by laboratory diagnosis (virus isolation: 13 cases; polymerase chain reaction: 30 cases, histology: 7 cases). One case was only diagnosed post mortem by polymerase chain reaction. Anamnesis of animal bites is contained in the clinical record of 58 cases with different species involved; scratching by unknown animals in 2 cases; in the 3 remaining cases, there was no record of an animal attack. Only 7 of the biting animals were tested for rabies, others are known to have been killed following the attacks on humans without having been investigated for rabies. None of the involved animals had a record of rabies vaccination. The leading role as a source of rabies among the 63 victims who died of rabies in Ukraine from 1996 to 2020 (Fig. 3). was identified for dogs and cats.

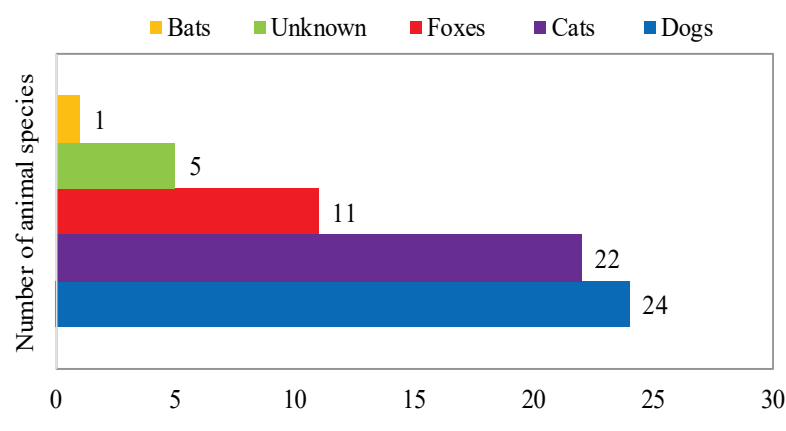

Fig. 3. The proportion of animal species involved in the 63 human rabies cases in Ukraine (1996-2020)

The majority (58.7\%) of the dogs (16) and cats (11) involved in the 63 rabies cases had owners. There were also 19 cases of attacks on people by stray dogs (8) and stray cats (11). We identified that dogs have increasingly become a source of rabies since 2003. Their proportion increased from $0 \%$ for the first 5 years' observation to $25.0 \%, 50.0 \%, 36.8 \%, 66.7 \%$ respectivly in the following 5-year periods (Fig. 4).

The reasons why rabies could not be prevented in the 63 human cases were diverse, dominated by the animal bite victims not seeking medical assistance $(\mathrm{n}=38 ; 60.3 \%)$, while the remaining animal bite victims sought medical assistance and died from rabies nevertheless $(n=25 ; 39.7 \%$, Table 1). A majority of the children among the rabies victims (11 out of 12) were in the group which did not seek medical assistance. Parents of these children did not have any risk perception and did not bring the child to a health facility, even though in 2 of these cases the parents were human and veterinary medicine professionals. Seventeen people sought medical assistance on the day of the animal's attack, 1 on the next day, 4 from the third to fifth days, and 3 within a week (up to the 7th and 8th days). The retrospective analysis findings indicate that all of these 25 patients had to undergo all courses of vaccination which were conducted in Ukraine in that period in accordance with the recommendations of the Ministry of Health (Table 2).
As presented in Table 2, some requirements of the instructions until 2016 did not always correspond to the WHO position on rabies vaccines. Particularly, it was regulated to start the post-exposure prophylaxis only in the case of the animal showing clinical signs of rabies or disappearance of the animal (without rabies immune globulin (RIG) or with RIG depending on the location, depth and number of injuries). Due to observance of this practice the onset of vaccination was delayed, or vaccination was not conducted. At the same time, for 15 patients the chance of survival was lost, as the post-exposure prophylaxis was not carried out. The following causes of rabies despite seeking medical assistance were reported: errors during animal quarantine (9.5\%); errors in diagnosis of rabies in animals (3.2\%); the refusal of PEP by the patient (6.3\%); failure to prescribe postexposure prophylaxis $(4.8 \%)$ (Table 1 , Table 2$)$. The remaining 10 patients out of 25 , who applied to health institutions, received post-exposure prophylaxis, but it turned out to be ineffective as was mentioned in Table 1 .

$$
\text { |- dogs I cats || wild | unknown }
$$

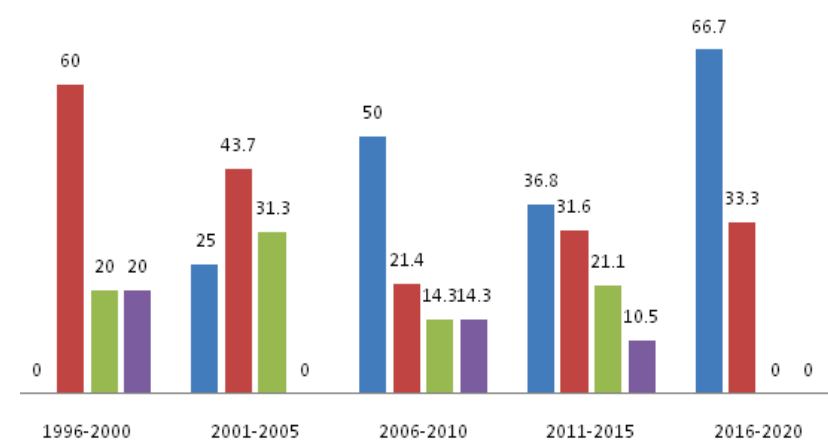

Fig. 4. Changes in the role of different animal species as sources of human rabies cases in ever 5-year period in Ukraine during 1996-2020

Table 1

The differentiation of the main reasons of rabies cases in humans in Ukraine (1996-2020), \%

\begin{tabular}{|c|c|c|c|c|}
\hline \multirow{2}{*}{$\begin{array}{l}\text { Not seeking } \\
\text { medical } \\
\text { assistance } \\
\text { after animal } \\
\text { attacks }\end{array}$} & \multicolumn{4}{|c|}{$\begin{array}{l}\text { Error and risk underestimation while referring } \\
\text { for medical assistance after animal attacks }\end{array}$} \\
\hline & $\begin{array}{c}\text { errors errors in } \\
\text { during diagnosis } \\
\text { animal of rabies } \\
\text { quarantinein animals }\end{array}$ & $\begin{array}{c}\text { refusal of rabies } \\
\text { postexposure } \\
\text { prophylaxis by } \\
\text { thepatient }\end{array}$ & $\begin{array}{l}\text { failure to pre- } \\
\text { scribe rabies } \\
\text { postexposure } \\
\text { prophylaxis }\end{array}$ & $\begin{array}{l}\text { failure of rabies } \\
\text { post-exposure } \\
\text { prophylaxis } \\
\text { (PEP) }\end{array}$ \\
\hline 60.3 & 9.5 & 6.3 & 4.8 & 15.9 \\
\hline
\end{tabular}

Among the reasons for post-exposure prophylaxis failures $(n=10$; 15.9\%): in 7 of these cases PEP was given without the use of RIG (patients No. 1, 2, 4, 5, 6, 9, 10); in 2 cases PEP failures were associated with the violation of appointment regimen and consumption of alcohol (patients No. 3, 7); and in 1 case, it is associated with the ineffectiveness of the vaccine (patient No. 8). The quality of the vaccine used in those cases has not been verified. Post-exposure prophylaxis was ineffective in victims of bites by foxes, by stray dogs and cats and bites by dogs and cats which had owners, with localization rates: face, shin, hand fingers, hip, etc. The full information regarding the PEP failures described in Table 3.

As can be seen from Table 3, the most common reasons for failure were scheme breach, late start of course of vaccination and absence of rabies immune globulin. In total, the analysis of visits by patients who suffered from contact with animals and the provision of post-exposure prophylaxis was carried out according to monitoring data for 13 years. During this period (2007-2019), from 65,916 to 106,496 victims of animal attacks were registered annually. An average of 84,148 people (187.4 per 100,000 of the population) was affected by animals every year, among which 2,155 people ( 4.8 per 100,000 of the population) suffered from rabid animals. Post-exposure prophylaxis was prescribed annually, on average, for 21,434 patients ( $25.4 \%$ of those who came for assistance after animal attacks). Among them, 2,155 people were victims of rabid animals as confirmed by the laboratory. By the end of each year, 14,619 patients or $68.0 \%$ of those who had been prescribed the vaccination completed the course and were immunized, and $14.3 \%$ continued the course of the vaccination. The course of vaccination was stopped by doctors in $7.7 \%$ of the 
cases after the laboratory exclusion of rabies in the animal or after the quarantine period for animals was over. In $9.0 \%$ of cases, patients refused to receive vaccinations or arbitrarily interrupted the course. $1.0 \%$ of those who received vaccination were lost to surveillance, possibly due to changing residence. In addition, by 2015, for post-exposure prophylaxis, predominantly, a Cocav vaccine, 6 doses into the shoulder muscle under the Essen regime (daily for 1 dose on 0, 3, 7, 14, 30 and 90th days) was used. Since 2015, other vaccines for 6 and 5-dose prophylactic vaccination
(Indirab, Verorab, Rabipur) have been used more often (Table 2). Taking into consideration the number of prescriptions of the combined course, the annual need for rabies immune globulin was on average $69 \mathrm{~L}$, and for vaccines more than 110,300 doses. The amount of vaccine used in practice was almost 3,000 doses less than the total need because the vaccine was not used in cases of refusal to vaccinate or after interruption of courses. Since 2011, there has been a sharp decline in the use of the vaccine in combination with rabies immune globulin (Fig. 5).

Table 2

The type of rabies vaccines used for humans in Ukraine from 1996 to 2020 according to the official statistical data of the Ministry of Health of Ukraine

\begin{tabular}{|c|c|c|c|c|c|c|c|c|}
\hline $\begin{array}{c}\text { Name } \\
\text { of vaccine }\end{array}$ & Description & $\begin{array}{l}\text { Years } \\
\text { of used }\end{array}$ & Manufacturer & Base & $\begin{array}{l}\text { Active ingredient/dose } \\
\text { activity, IU*/mL }\end{array}$ & $\begin{array}{c}\text { Dose, } \\
\text { injection site }\end{array}$ & $\begin{array}{c}\text { Mode of } \\
\text { administration }\end{array}$ & $\begin{array}{l}\text { Delaying the start } \\
\text { of the PEP** }\end{array}$ \\
\hline $\mathrm{Cav}$ & $\begin{array}{l}\text { Rabies culture inacti- } \\
\text { vated dry vaccine for } \\
\text { human immunization } \\
\text { (Rabivac-Vnukovo-32) }\end{array}$ & Till 2004 & $\begin{array}{l}\text { Microgen, } \\
\text { Russia; } \\
\text { Bereh-service, } \\
\text { Ukraine }\end{array}$ & $\begin{array}{l}\text { Primary culture } \\
\text { of the kidney } \\
\text { cells of Syrian } \\
\text { hamsters }\end{array}$ & $\begin{array}{c}\text { Rabies virus } \\
\text { Vnukovo-32 strain } \geq 0.5\end{array}$ & $\begin{array}{c}3.0-5.0 \mathrm{~mL} \\
\text { by intradermal }\end{array}$ & $\begin{array}{l}7-12 \text { days; booster } \\
\text { dose on the } 10 \text { th, } 20 \text { th } \\
\text { day after the main } \\
\text { course }\end{array}$ & Yes \\
\hline Cocav & $\begin{array}{l}\text { Rabies culture inacti- } \\
\text { vated concentrated } \\
\text { purified dry vaccine }\end{array}$ & $\begin{array}{l}\text { From } 1999 \\
\text { to } 2014\end{array}$ & $\begin{array}{l}\text { Microgen, } \\
\text { Russia }\end{array}$ & $\begin{array}{l}\text { Primary culture } \\
\text { of the kidney } \\
\text { cells of Syrian } \\
\text { hamsters }\end{array}$ & $\begin{array}{c}\text { Rabies virus } \\
\text { Vnukovo-32 strain } \geq 2.5\end{array}$ & $\begin{array}{l}1 \mathrm{~mL} \text { intramuscular } \\
\text { (deltoid area) }\end{array}$ & $\begin{array}{l}0,3,7,14 \\
30,90 \text { days }\end{array}$ & Yes \\
\hline Verorab & $\begin{array}{c}\text { Rabies vaccine for } \\
\text { human use, prepared on } \\
\text { cell cultures (inacti- } \\
\text { vated) }\end{array}$ & Since 2004 & $\begin{array}{l}\text { Sanofi Pasteur, } \\
\text { France }\end{array}$ & Vero cell culture & $\begin{array}{c}\text { Rabies virus, Wistar } \\
\text { Rabies PM/WI 38- } \\
1503-3 \mathrm{M} \text { strain (inacti- } \\
\text { vated) } \geq 2.5\end{array}$ & $\begin{array}{c}0.5 \mathrm{~mL} \\
\text { intramuscular } \\
\text { (deltoid area) }\end{array}$ & $\begin{array}{c}\text { WHO: Essen regi- } \\
\text { men: } 0,3,7,14,28 \\
\text { days. Zagreb regi- } \\
\text { men: } 2,1,1(0-2,7,21)\end{array}$ & No \\
\hline Indirab & $\begin{array}{c}\text { Rabies, inactivated, } \\
\text { whole virus Pitman } \\
\text { Moore }\end{array}$ & Since 2010 & $\begin{array}{l}\text { Bharat Biotech } \\
\text { International } \\
\text { limited, India }\end{array}$ & Vero cell culture & $\begin{array}{c}\text { Rabies virus } \\
\text { Pitman Moore } \\
\text { strain } \geq 2.5\end{array}$ & $\begin{array}{c}0.5 \mathrm{~mL} \\
\text { intramuscular } \\
\text { (deltoid area) }\end{array}$ & $\begin{array}{l}\text { Ministry of Health of } \\
\text { Ukraine } 0,3,7,14, \\
28,90 \text { days. Since } \\
\text { 2016, WHO: } 0,3,7 \text {, } \\
24,28 \text { days }\end{array}$ & Yes, till 2016 \\
\hline Rabipur & $\begin{array}{l}\text { Rabies, inactivated, } \\
\text { whole virus }\end{array}$ & Since 2016 & $\begin{array}{l}\text { Kyron Bering } \\
\text { Vaccines Pri- } \\
\text { vate, India }\end{array}$ & $\begin{array}{l}\text { Primary culture } \\
\text { of fibroblasts of } \\
\text { chicken em- } \\
\text { bryos }\end{array}$ & $\begin{array}{l}\text { Inactivated rabies virus } \\
\text { Fluru LEP strain } \geq 2.5\end{array}$ & $\begin{array}{l}1 \mathrm{~mL} \text { intramuscular } \\
\text { (deltoid area) }\end{array}$ & $\begin{array}{l}\text { WHO: } 5 \text {-dose: } 0,3,7 \text {, } \\
\text { 24, } 28 \text { days (since } \\
\text { 1997) Abbreviated: } 2, \\
1,1(0,7,21 \text { days) }\end{array}$ & No \\
\hline
\end{tabular}

Notes: *IU - International Unit; ** - delayed start of the post-exposure prophylaxis means start of vaccinations with the appearance of signs of an animal's disease or its disappearance in accordance with requirements of "The instructions of the Ministry of Health of Ukraine".

Table 3

List and possible causes of post-exposure prophylaxis failures in 10 rabies victims in Ukraine (1996-2020)

\begin{tabular}{|c|c|c|c|c|c|c|c|c|}
\hline Year & Age & $\begin{array}{l}\text { Source/rabies } \\
\text { test result }\end{array}$ & $\begin{array}{l}\text { Localization } \\
\text { of injuries }\end{array}$ & $\begin{array}{l}\text { PEP day } \\
\text { after attack }\end{array}$ & $\begin{array}{l}\text { Drugs } \\
\text { received* }\end{array}$ & $\begin{array}{l}\text { Incubation } \\
\text { period }\end{array}$ & $\begin{array}{l}\text { Recommendations for vaccine } \\
\text { guidelines: category of injuries; } \\
\text { drug administration scheme }\end{array}$ & $\begin{array}{l}\text { Possible causes } \\
\text { of PEP failures }\end{array}$ \\
\hline 1997 & 49 & fox/negative & $\begin{array}{l}\text { face, fingers, } \\
\text { forearms, } \\
\text { body }\end{array}$ & 1 & $\begin{array}{l}\text { Cav } \\
\text { main treat- } \\
\text { ment course }\end{array}$ & 30 days & $\begin{array}{c}\text { Bad case; Rabies immune globulin (RIG) } \\
+ \text { Cav } 5.0 \times 21 \text { days. Revaccination on } \\
\text { 10th, 20th, } 35 \text { th days after main treatment } \\
\text { course }\end{array}$ & $\begin{array}{l}\text { Scheme breach: RIG was not } \\
\text { administered (not available) }\end{array}$ \\
\hline 2001 & 11 & $\begin{array}{l}\text { home cat/ } \\
\text { positive }\end{array}$ & shin & 2 & $\begin{array}{c}\text { Cav } \\
3.0 \times 12+2\end{array}$ & 32 days & $\begin{array}{c}\text { Light injuries; Cav } 3.0 \times 12 \text { days. Revac- } \\
\text { cination on the } 10 \text { th, } 20 \text { th day after the } \\
\text { main treatment course }\end{array}$ & $\begin{array}{l}\text { Inadequate assessment of the contact nature, } \\
\text { inadequate PEP course (without RIG). The } \\
\text { effect of acute respiratory infection when } \\
\text { receiving PEP is not excluded }\end{array}$ \\
\hline 2001 & 27 & fox/notest & $\begin{array}{l}\text { data not } \\
\text { available }\end{array}$ & 1 & $\begin{array}{l}\text { RIG, Cav } \\
\text { main treat- } \\
\text { ment course }\end{array}$ & $\begin{array}{l}\text { data not } \\
\text { available }\end{array}$ & $\begin{array}{l}\text { RIG }+ \text { Cav } 5.0 \times 21 \text { days. Revaccination } \\
\text { on the } 10 \text { th, } 20 \text { th, } 35 \text { th day after the main } \\
\text { treatment course }\end{array}$ & $\begin{array}{l}\text { Scheme breach: did not show up at revacci- } \\
\text { nation on the 10th, 20th, 35th day. Alcohol } \\
\text { drinking during PEP }\end{array}$ \\
\hline 2003 & 44 & $\begin{array}{l}\text { stray dog/ } \\
\text { no test }\end{array}$ & shin & 1 & $\begin{array}{c}\text { Cav } \\
3.0 \times 12+2\end{array}$ & 105 days & $\begin{array}{l}\text { Light injuries Cav } 3.0 \times 12 \text { days, revacci- } \\
\text { nation on the } 10 \text { th, } 20 \text { th day after the } \\
\text { treatment course }\end{array}$ & $\begin{array}{l}\text { This category of risk does not include RIG } \\
\text { administration. No RIG administration due to } \\
\text { underestimation of risk. Stitching the wound. }\end{array}$ \\
\hline 2004 & 32 & fox/no test & nose & 2 & 4 Cocav & 34 days & $\begin{array}{c}\text { Category III b** RIG Cocav } 0,3,7,14 \text {, } \\
30,90\end{array}$ & Scheme breach: RIG was not administered \\
\hline 2005 & 68 & $\begin{array}{l}\text { home dog/ } \\
\text { no test }\end{array}$ & $\begin{array}{c}\text { data not } \\
\text { available }\end{array}$ & 5 & 4 Cocav & 42 days & $\begin{array}{c}\text { Category III a*** } \\
\mathrm{RIG}+\text { CoCAV } 0,3,7,14,30,90\end{array}$ & $\begin{array}{l}\text { Late PEP start. Scheme breach: } \\
\text { RIG was not administered }\end{array}$ \\
\hline 2007 & 41 & fox/positive & $\begin{array}{l}\text { fingers } \\
\text { of the hand }\end{array}$ & 5 & $\begin{array}{l}\text { RIG, } \\
\text { 4 Cocav }\end{array}$ & 27 days & $\begin{array}{c}\text { Category III } \\
\text { RIG Cocav } 0,3,7,14,30,90\end{array}$ & $\begin{array}{l}\text { Late PEP start. Not enough RIG dose Cocav- } \\
\text { the next day Alcohol drinking during PEP. }\end{array}$ \\
\hline 2007 & 4 & $\begin{array}{l}\text { stray cat/ } \\
\text { positive }\end{array}$ & hand fingers & 1 & $\begin{array}{l}\text { RIG, } \\
\text { 6Cocav }\end{array}$ & 103 days & $\begin{array}{c}\text { Category III } \\
\mathrm{RIG}+\text { Cocav } 0,3,7,14,30,90\end{array}$ & Low immunizing power of the vaccine \\
\hline 2013 & 34 & $\begin{array}{l}\text { stray dog/ } \\
\text { no test }\end{array}$ & hip & 8 & $\begin{array}{l}2 \text { Cocav } \\
4 \text { Indirab }\end{array}$ & 150 days & $\begin{array}{l}\text { Category III The mode of joint use of } \\
\text { Cocav and Indirab is not regulated }\end{array}$ & $\begin{array}{l}\text { Late start of PEP, Scheme breach: } \\
\text { RIG not administered (not available). Differ- } \\
\text { ent vaccines }\end{array}$ \\
\hline 2014 & 63 & fox/no test & face & 1 & 4 Cocav & 45 days & $\begin{array}{c}\text { Category III } \\
\text { RIG }+ \text { Cocav } 0,3,7,14,30,90\end{array}$ & $\begin{array}{l}\text { Scheme breach: RIG was not administered } \\
\text { (not available) }\end{array}$ \\
\hline
\end{tabular}

Notes: * Cav, Cocav, Indirab - cultural rabies vaccines; the assertion that "vaccines from different manufacturers for the prevention of the same infectious diseases can be interchangeable" does not apply to vaccines Cocav and Indirab; ** - category III b: any bite or slobbering of any localization made by a wild camivorous animal or a bat; *** Category III a: slobbering of damaged mucous membranes, any bite in the head or face, neck, fingers of the hands, perineum, genital wide or deep bites of any localization, multiple ( 2 or more) bites of a domestic animals. 


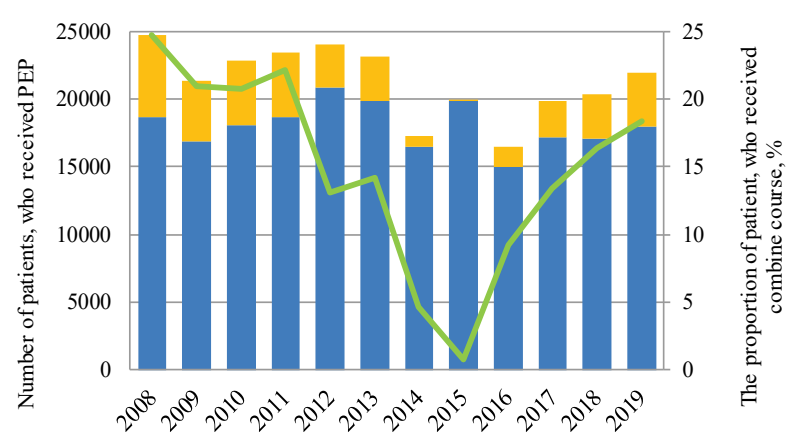

Fig. 5. The number of people who received the prophylactic vaccination courses during 2008-2019: blue colour - only vaccine; yellow colourvaccine and rabies immune globulin; green colour - the percentage of combined courses (vaccine and rabies immune globulin)

On this curve, we can find a decrease in use of rabies immune globulin during 2014-2016 and also less use of vaccines. In our investigation, we identified that human rabies cases were confirmed in the period when rabies was endemic in the territory of Ukraine with numerous of rabies cases in animals. As we can see from the curve (Fig. 6), rabies cases were registered each year and counted on average of 1,600 cases per year with a peak in 2007 among animals.

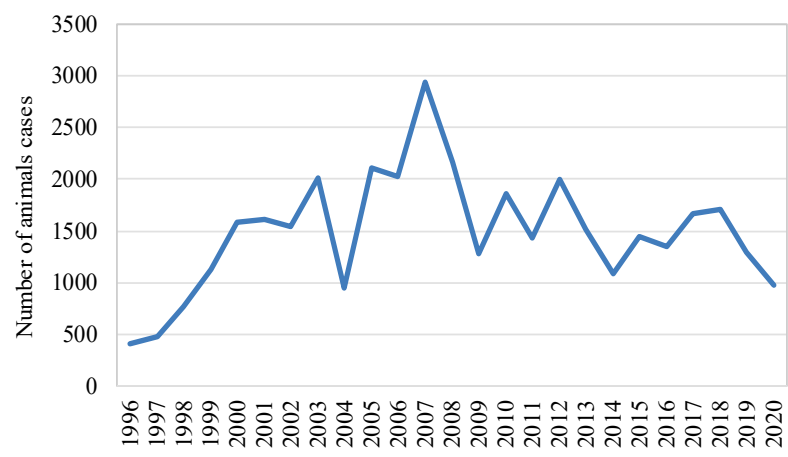

Fig. 6. Dynamics of rabies cases among animals in Ukraine (1996-2020) according to annual official reports from oblast departments of the State Service of Ukraine for Food Safety and Consumer Protection

During 1996-2020 in Ukraine, there were about 37,338 cases of rabies among 18 species of wild and 10 species of domestic animals. Most of these cases were identified from domestic carnivores. However, most often rabies was detected among foxes $-37.3 \%$, and among other wild animals $-2.9 \%$. The share of rabid dogs was more than $19.3 \%$, cats $24.7 \%$, farm animals $-15.8 \%$. According to the results of epidemiological surveillance for rabies during 2007-2019, the largest proportion of animal attacks on people was from dogs $(77.7 \%)$; the highest proportion of attacking animals actually diagnosed with rabies virus occurred in cats (32.9\% of all rabid animals, Table 4$)$.

\section{Table 4}

The comparison of the frequency of seeking medical assistance by patients who had suffered from different animals species according to annual official reports from oblast laboratories of Ministry of Health of Ukraine (cases that have been analyzed 2007-2019)

\begin{tabular}{lrrrrrr}
\hline \multirow{2}{*}{$\begin{array}{c}\text { Species of animals } \\
\text { which attacks humans }\end{array}$} & \multicolumn{1}{c}{ Attacks by all animals } & \multicolumn{3}{c}{ Attacks by rabid animals } \\
\cline { 2 - 7 } & \multicolumn{1}{c}{ total } & average & \multicolumn{1}{c}{$\%$} & \multicolumn{1}{c}{ total } & average & \multicolumn{1}{c}{$\%$} \\
\hline Dogs & 838,635 & 64,510 & 77.7 & 6,747 & 519 & 28.8 \\
Cats & 196,128 & 15,087 & 18.2 & 7,717 & 593 & 32.9 \\
Farm animals & 11,525 & 886 & 1.1 & 4,581 & 352 & 19.5 \\
Wild predators & 11,986 & 923 & 1.1 & 1,240 & 320 & 17.7 \\
Bats & 1,407 & 108 & 0.1 & 20 & 1 & 0.1 \\
Rodents & 14,430 & 1,110 & 1.3 & 159 & 12 & 0.6 \\
Other & 5,071 & 390 & 0.5 & 88 & 7 & 0.4 \\
\hline Total number of attacks & $1,079,182$ & 83,014 & 100 & 23,452 & 1,804 & 100 \\
\hline
\end{tabular}

During 13 years among 1,079,182 analyzed cases of appeals for medical assistance following animal attacks, 1 in 124 dog attacks on humans was committed by rabid dogs $(6,747$ out of 838,635$)$, so the risk of rabies infection from dogs was 1:124 (Table 4). The risk of cats involved in attacks being rabid was 1:25 (7,717 out of 196,128). Medical cases associated with attacks of wild animals had a proportion of every seventh biting animal being rabid (risk 1:7-4,397 out of 32,894). Among contacts with farm animals, nearly every second case was found to be a contact with a rabid animal (risk 1:2). It should be noted the majority of attacks by cats and dogs involved animals that had owners $(71.5 \%)$. The proportion of stray cats and dogs involved in attacks was $27.4 \%$. The largest number of victims from animals was in $2008(n=106,496)$, and the smallest - in $2014(\mathrm{n}=65,916)$. In general, the number of victims from attacks by animals per 100,000 humans in the last decades was from 230.5 to 153.6 per year (Fig. 7).

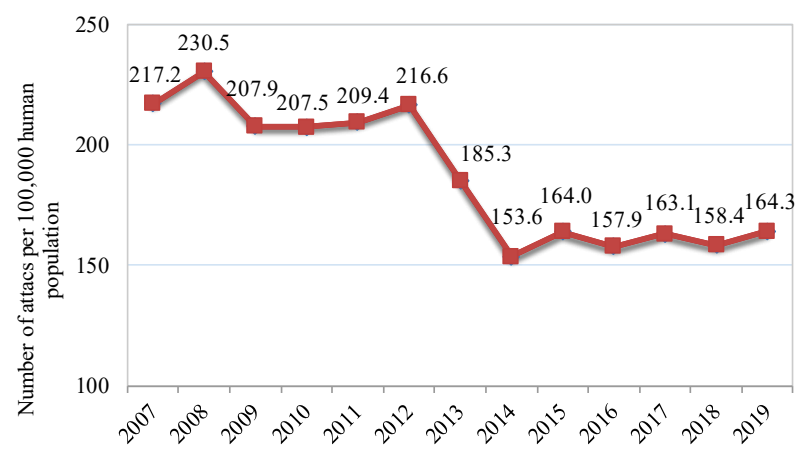

Fig. 7. Number of victims from attacks by animals registered in Ukraine per 100,000 human population (2007-2019)

The number of such cases has decreased significantly over the past 7 years and from 2014 did not exceed 165.0 per 100,000 of the human population. The features of geographical distribution were specific for different species of animals. For our analysis, the most important task was to study the spatial distribution of animals which were the main sources of rabies for humans. Firstly we conducted a spatial analysis for dogs. During the study period, a high number of dog attacks were observed in the East of Ukraine, especially in Donetsk and Kirovograd oblasts (Fig. 8a).

When we compared distribution of attacks from rabid dogs we identified almost the same tendency, but in this case, the greatest number of dog bites was identified on the territory of four eastern oblasts (Fig. 8b). Regarding cats, a high number of cat attacks were identified in the East of Ukraine as well (especially in Donetsk, Kirovograd and Kharkiv oblasts), in the South part of Ukraine (Odesa oblast) and also in the capital of Ukraine, Kyiv city (Fig. 9a).

A high number of attacks from rabid cats was found also in the East of Ukraine (especially on the territory of Kharkiv oblast) and also along boundaries with Russian Federation as well as on the north part near the Republic of Belarus (Fig. 9b). The most important reservoir of rabies among wild animals was foxes. In comparison with dogs and cats, a high number of attacks from foxes were identified in each oblast, but most concentrated in some Western oblasts, such as Vinnytsia, Zhytomyr and Volyn. The lowest number of bites from foxes was registered in the capital of Ukraine, Kyiv city (Fig. 10a).

The highest number of attacks from rabid foxes was observed in Vinnytsia oblast. At the same time almost in each oblast except 5 (among 24 overall) many attacks by rabid foxes were reported (Fig. 10b). Numerous attacks were observed along borders with Moldova, Poland, the Republic of Belarus and the Russian Federation. A minimal number of bites from rabid foxes were observed in the central part of Ukraine. Since one animal can contact a few humans, in general there were registered about 400 attacks on humans per oblast by domestic carnivores and 100 by wild carnivores. The number of attacks by rabid animals was also high, accounting for about 100 attacks from dogs and cats and 40 from foxes per oblast.

\section{Discussion}

This article includes for the first time long-term data on the causes of human deaths from rabies, the most important problems and gaps in knowledge on measures to prevent rabies and an assessment of the risk of 
animal attacks in view of their species and geographical distribution, taking into account the epizootic and epidemic situation of rabies in Ukraine in 1996-2020.

During 25 years, 63 people died of rabies, and unfortunately, this trend is intensifying over the years. The situation is not quite defined, as the possibility of incomplete accounting of cases due to underdiagnosis is not excluded. Due to limited laboratory capabilities for diagnosing rabies

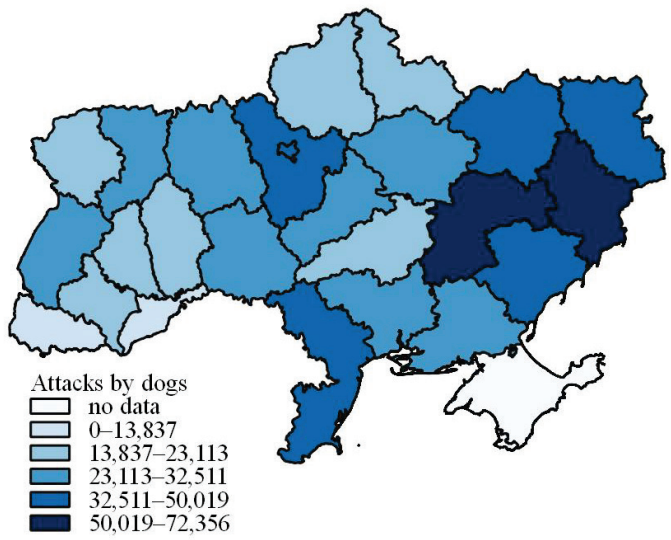

in humans, rabies could occur under other diagnoses. Quoting Chikanya et al. (2020) the incidence of human rabies in Europe is very low, both for cases contracted in Europe and imported from endemic countries. In contrast to the animal data, the global trend of reported human data over time suggests relative stability in the number of cases reported. Indigenous cases were mostly reported from Eastern Europe, corresponding to patients bitten by stray or aggressive domestic dogs or foxes.

Fig. 8. Geographical distribution of attacks from dogs on the territory of Ukraine (2007-2019): $a$ - from all dogs, $b$ - from rabid dogs
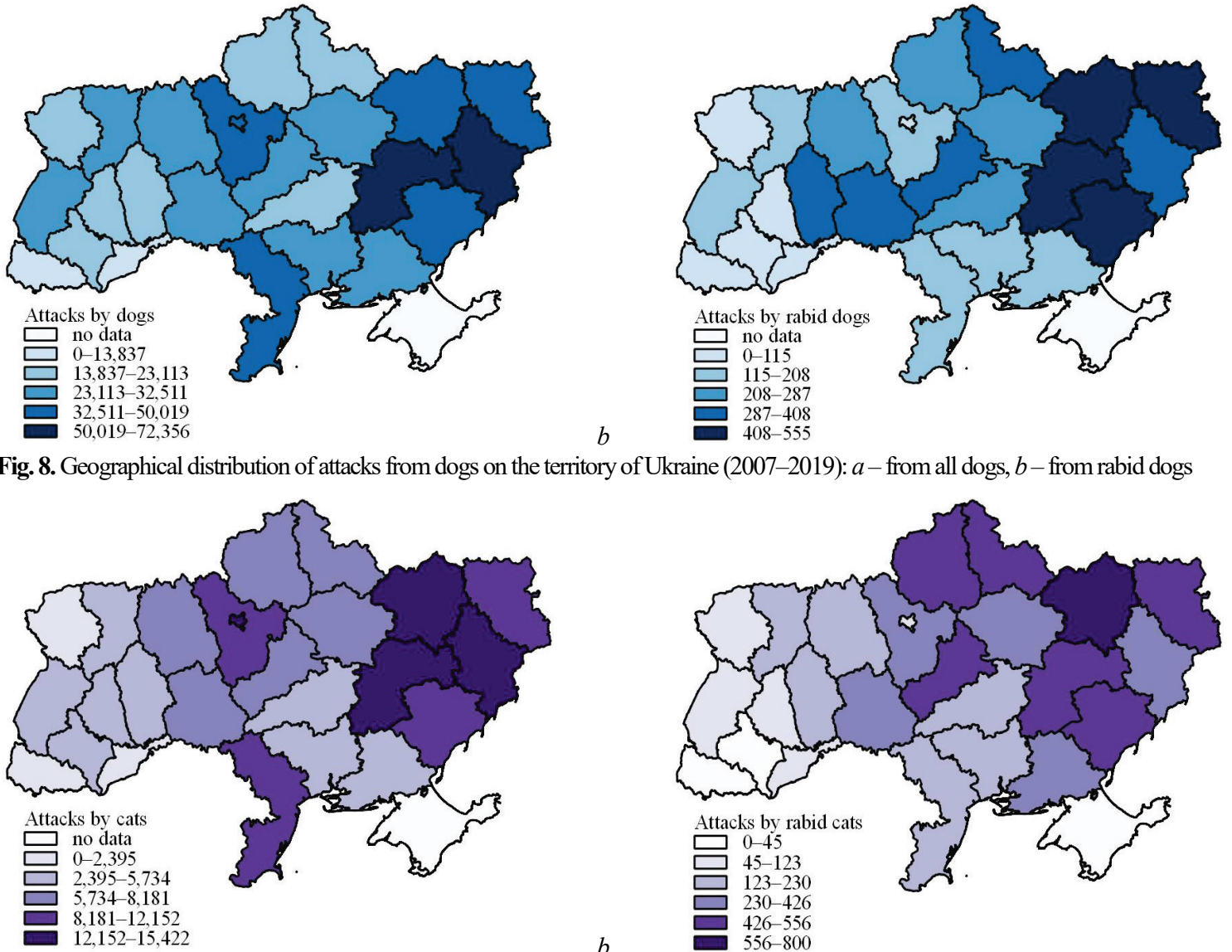

Fig. 9. Geographical distribution of attacks from cats on the territory of Ukraine (2007-2019): $a$-from all cats, $b$-from rabid cats
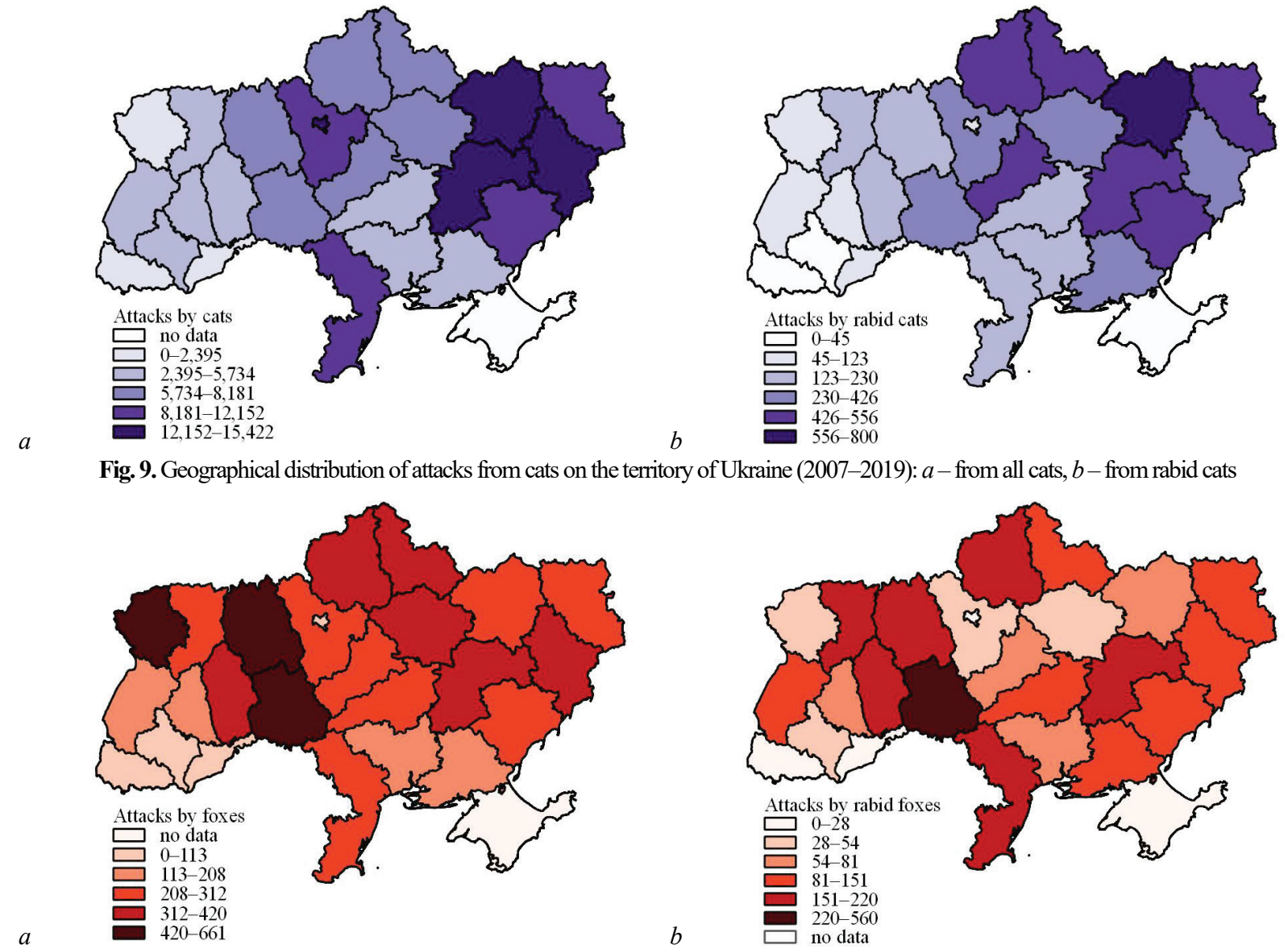

Fig. 10. Geographical distribution of attacks from foxes on the territory of Ukraine (2007-2019): $a$ - from all foxes, $b-$ from rabid foxes

The current definition in Ukraine of confirmed cases according to diagnostic criteria, when there are clinical manifestations and laboratory confirmation of rabies, includes 50 cases. The remaining 13 cases were probable, without laboratory research, but with an epidemiological link and met the clinical criteria for the diagnosis of rabies (acute encephalitis, and at least two of the following symptoms: change in sensitivity at the site of the bite, paresis or paralysis, muscle spasms, fear of water, delirium, convulsions, anxiety). The highest number of human rabies cases was observed in $2007(n=7)$. This could be explained by the peak of rabies cases in animals in 2007 (Fig. 6). Due to an increase of over 100\% in the number of cases of animal rabies in 2006-2007 compared to 2005, the frequency of requests for medical assistance also increased $-4,732 \mathrm{hu}-$ mans were affected by rabid animals in 2007. After that, the number of such attacks and their victims slowly decreased by 2019 to 1,161 . According to Yoder et al. (2019), the increase in rabies in dogs by $10.0 \%$ is associated with an increase in human morbidity by $6.3 \%$. In our study, the number of rabies cases among attacking dogs increased by 2007 to 1,121 and then decreased by 2019 to 337 (by 33.0\%). But during all this time, 40 people died from rabies and the source of the rabies virus for 24 of them was dogs. In the 12 years preceding 2007, 23 people died and only 2 after dog attacks. Regarding geographical distribution, the largest number of human rabies cases was confirmed in the east of Ukraine (Donetsk 
-10 , Kharkiv - 7) in more populated, urban areas, dominated by the high density of the human population and domestic animals respectively, which had a major role as sources of the rabies virus for humans. Sporadic cases occurred in almost every administrative territory, except for the Crimean peninsula and five small western regions.

During 13 years, the proportion of the risk of attacks by rabid dogs as compared of a general number of dogs attacks on humans was 1:124, which is significantly less than the risk of rabies from cats (1:25), wild animals (1:7) and farm animals (1:2). But it is important to note that dogs are in constant contact with people, the number of their attacks is more than three times higher than the number of attacks by other animals. In addition, attacks are more often reported from domestic dogs, which is confirmed by the fact that owners are irresponsible with their animals and by the lack of conducting vaccination measures, so the risk of transmission of rabies from dogs remains the most anticipated.

Geographical features of animal attacks also have certain patterns. For instance, in the territories of eastern Ukraine, where there is a large human population with a high density of domestic carnivores, there are more attacks by dogs and cats (Makovska, 2020a). Also in places of the higher human population there is a higher number of stray domestic carnivores. As noted by Warembourg et al. (2021) the higher density of stray dogs was associated with closeness to potential food sources such as commercial food places and a university restaurant. Besides this, due to the rabies transboundary disease, the permanent endemic situation of eastern oblasts can be linked with sick animals which can move from neighbouring countries with endemic rabies, such as the Russian Federation and the Belarus Republic (Mogilevsky, 1997; Makovska et al., 2018). Quoting Baker et al. (2020), incursions from other regions account for less than $1.0 \%$ of cases but allow for re-emergence of the disease. The aforementioned also was submitted by Polupan et al. (2021) during their study, the genetic sequences of the studied samples from Ukraine are characteristic of isolates isolated in the Russian Federation, South-Eastern Europe, Western Siberia, and Kazakhstan. Similar results were received by PicardMeyer et al. (2012) when they investigated samples from Ukraine. In the central and western oblasts, where population density is lower and there are more fields and forests, there was a large number of fox attacks, as was evidenced previously by another author (Freuling, et al., 2013; Makovska, 2020b).

Besides this, we determined that for a long time, cats were the main source of rabies for people in Ukraine. But, over the past 20 years, the role of dog transmission of the rabies virus to humans has increased significantly to $66.7 \%$ (Fig. 4). The beginning of the increase was observed in 2003. It can be explained by the reduction in efforts for vaccination of domestic carnivores and reduction in attention paid to pets due to the start of the ORV campaign in 2001 (Makovska et al., 2020). In addition, the risks of human infection with the rabies pathogen transmitted by dogs are increasing due to their owners' failure to comply with the rules of animal keeping, a lower level of vaccination of pets, low-level of public awareness and absence of expert appraisal and increasing of the dog population. As reported by Kornienlko et al. (2019) according to various estimates, there are between 6-8 million dogs kept in Ukraine and the number of homeless animals of this species can be 10-20 thousand per city (oblast centre). As asserted by Roebling (2014), responsible pet ownership, universal rabies vaccination of pets and removal of strays remain integral components to control rabies and other diseases.

In general, control of rabies in domestic carnivorous remains relevant. Among the human victims of rabies, 24 had dangerous contact with dogs and 22 with cats. Among these animals, 19 were homeless and 25 had owners. No animal was vaccinated against rabies. Twelve patients out of 63 who died of rabies died following attacks by wild animals, including 1 from a bat and 11 from foxes. It is known that the incubation period for victims of fox attacks in one case lasted 3 years. The sources of rabies in 5 patients out of the 63 cases studied are unknown. In one case, rabies was diagnosed in the laboratory after the death of the patient, in another - the diagnosis occurred during life, but the history is unknown. Three did not remember contact with the animals. A total of 12 children aged 3 to 17 died of rabies. Young children tend to be attacked by animals due to neglect, and older children are afraid to confess to their parents about an attack. But in all cases, the precondition was the ignorance of both adults and children about the dangers of contact with animals. The behaviour of the majority of victims in relation to medical treatment was rather poor, more than $60.0 \%$ ( 27 adults and 11 children) did not apply for postexposure prophylaxis, almost $25.0 \%$ suffered from their own pets. Obviously, the people were not sufficiently informed about rabies - clearly, there is a need to implement educational prevention campaigns. The fact that 12 victims of rabies were children and that among their parents there were medical and veterinary professionals suggests that children should be included in the target audience, and the training of professionals should be improved. Ignorance can also be seen in the fact that only 7 animals that attacked rabies victims were examined in the laboratory. In other cases, when animals were killed or killed after the attacks on people, these events were not reported anywhere, visits to medical facilities did not take place. As a result, in 38 cases, people died due to ignorance, irresponsible ownership of animals, neglect of their own health and people's neglect of the health of other people and animals. They lost their chance to survive because they did not seek help to obtain a post-exposure prophylaxis. The remaining 25 patients out of 63 sought help after animal attacks. Because rabies can be prevented in a person who has had dangerous contact with a sick animal with the help of post-exposure prophylaxis, this should be done as soon as possible after dangerous contact with the animal, and the amount of PEP should correspond to the category of damage. But the vaccine was not always available during the study period.

Since 2003 rabies vaccines for human immunization have not been produced in Ukraine. From the same year, deliveries of rabies immunoglobulin to medical institutions were suspended and deliveries of rabies vaccine financed from the state budget were significantly reduced. The function of providing immunoglobulin was entrusted to local budgets. In recent years, the volume of vaccine supplies from the state budget has increased. But not all local budgets are ready to spend on rabies immunoglobulin (Antonova et al., 2021). As noticed by Grigoryan \& Metlin (2016) in countries where there is no local production of anti-rabies vaccines, governments and other donors are likely to subsidize a limited number of doses of rabies vaccine, which will reduce their availability. This situation can be exacerbated by two factors: 1) the lack of rabies immunoglobulin for treatment; 2) the fact that pharmaceuticals must be imported, which leads to a lack of access due to the high price.

Due to limited budgets, disruptions in the manufacture of rabies immunoglobulin in Ukraine, hospitals have not always provided a permanent supply of rabies vaccines and immunoglobulin, thus patients have not always been able to buy drugs in the pharmaceutical network due to their high cost. This situation has caused the unwillingness of adequate (timely and in full) provision of medical care by medical staff; loss of access and unequal access to patient care, as a result we have experienced nonvaccination, refusal, or incomplete vaccination without the use of rabies immunoglobulin $(\mathrm{n}=8)$. Due to incorrect requirements in the instructions (Table 2), the observation of animals was mistakenly conducted on other animals than the ones which were the source of the biting attack, and in the other 3 cases, the animals concerned were killed or their death within 10 days of the attack on a person was not reported (Table 1). Thus, the main reason for post-exposure prophylaxis failures is not the quality of vaccines, but the violation of vaccination schemes, non-use of immunoglobulin. This statement is confirmed in our study. The greater number of people did not receive immunoglobulin, although they suffered from attacks by foxes and stray animals and suffered an injury to dangerous locations. Only one case of PEP failure was related to the ineffectiveness of the Cocav vaccine, but the evidence was not convincing. An important element of rabies surveillance is the diagnosis of the disease in both humans and animals. In 2 cases, the reasons for rabies developing in humans were a delay in the verification of animal rabies in combination with delaying the onset of PEP and waiting for laboratory results. In such a situation, medical prophylaxis of rabies is the last chance, when the salvation of people's lives depends on the organization and quality of practical implementation.

The role of animals is found for each case, which is ensured by the close interaction of two sectors of health care: humans and animals. Every year more than 80,000 victims of animal attacks occur, about 20,000 people are vaccinated. In addition, $71.5 \%$ of victims of the attack suffer from dogs and cats that had owners. Thus, irresponsible possession of 
animals occurs due to imperfect legislation in this area. The share of attacks from stray cats and dogs was $27.4 \%$, but it was due to attacks from homeless animals that about 17,000 people a year had to be vaccinated as a high-risk group, because of the impossibility of observing homeless animals and also of conducting post-mortem laboratory tests on them in order to exclude rabies. Such a difficult situation regarding stray animals described in the literature (Cliquet et al., 2014; Roebling et al., 2014). According to the investigation of Chikanya (2021), in some countries of southeastern Europe, homeless dog populations also very high and their supervision difficult. This carries a high risk of threatening human health and animal welfare.

The highest number of attacks was in 2008 , which can be explained by the highest peak among animals in 2007 . This contributed to the wider spread of the disease among animals, which increased the incidence of rabies, animal aggression and, consequently, the number of attacks on humans. A similar statement is confirmed in the works of Yoder et al. (2019). The results show a positive relationship between current reported contacts and rabies cases in dogs and humans in the previous year. This suggests that past cases of rabies in humans and dogs are important events for assessing the risk of current exposure, which showed that the disease resonates over the next year. The smaller number of attacks in 2014 is explained by the beginning of political conflicts on the territory of Ukraine, which affected the quality of monitoring, both among animals and among people. Besides this as suggest by Antonova et al. (2021) given that as a result of hostilities some territories of the eastern regions of Ukraine, as well as the Crimean Peninsula were separated from Ukraine to Russia, the total number of attacks and requests for medical aid has decreased accordingly. Due to the difficult political situation between Ukraine and the Russian Federation, which previously provided us with its vaccines, an absence of a vaccine was observed, also cases of redistribution of vaccine residues between institutions, and a search for drugs in other areas and even abroad. Thus, in 2016, out of 9 administrative areas, 786 cases were reported when patients did not receive PEP or PEP was not prescribed.

Previously for collaborating in the eradicatation of rabies in Ukraine, there were programmes aimed at preventing animal rabies. In 2008 the state programme of rehabilitation of the territory of Ukraine from rabies for 2008-2015 was adopted. The crucial task of the Programme was a comprehensive solution to the protection of humans and animals (wild, domestic, farm) from rabies and finally to eradicate this disease in our country. According to Kornienko et al. (2019) despite the conducting of campaigns of oral and parenteral vaccination among wild and domestic animals in Ukraine, they did not achieve great success. In addition, the lack of registration of domesticated companion animals and the ability to control their immune status prevents proper planning and evaluation of the effectiveness of immune prevention of rabies. The last comprehensive programme, which provided for intersectoral cooperation at the state level, was completed in 2010. Since then, the same rabies prevention programs have been developed and implemented at the oblast and rayon levels. The need for coordination at the central level is palpable. Nowadays the deficiencies in the fight against rabies, as well as other zoonoses, are the lack of agreed coordination of inter-sectoral interactions on the central level, the attitude towards zoonoses as non-priority problems, the lack of funding for prophylaxis programs, and the use of old methods of interventions. As noticed by Fahrion et al. (2017) for any public health program, permanent funding resources are essential for continuing a rabies control programme, and the lack of those resources is one of the primary barriers to eradicating the fatal disease.

As we compare Ukraine's experience with that of other countries that have succeeded in overcoming rabies, it is clear that this work takes considerable time. This happens even when the activities are carried out under a comprehensive programme and have financial support (Taylor et al., 2021). The concept of the frame of "One Health" approach has highlights the integral division of responsibilities between institutions focused on animal health and human health (Wallace et al., 2017; Acharya et al., 2020). We recommend strengthening health applications against rabies by health workers, using a "One Health" approach by multiple stakeholders in Ukraine, and stepping up and monitoring the effectiveness of regular pet vaccination campaigns by the Veterinary Departments in each oblast and conducting further assessments of pets bites and controlling all rabies measures.

\section{Conclusions}

Overall, during 25 years (1996-2020) about 37,338 cases of rabies among animals and 63 cases among humans were registered. The leading source of rabies for human cases was dogs (24) and cats (22). The main causes of death were absence of seeking medical assistance after animal attacks (60.3\%), error and underestimation of risk during referral for medical assistance after animal attacks (39.7\%), errors during animal quarantine $(9.5 \%)$, errors in diagnosis of rabies in animals (3.2\%), refusal of PEP by the patients $(6.3 \%)$, failure to prescribe PEP $(4.8 \%)$, failure of PEP $(15.9 \%)$.

During the last 13 years (2007-2019) on average, about 84,148 people (187.4 per 100,000 population) suffered from animals attacks every year, among which 2,155 people (4.8 per 100,000 population) were affected by rabid animals. PEP was prescribed annually, on average, for 21,435 patients, from which by the end of each year, 14,619 (68.0\%) patients had completed the course and were immunized. The frequency of the proportion of the risk of attack by rabid dogs compared to the total number of dog attacks on humans was (1:12) from cats (1:25), wild animals (1:70) and farm animals (1:20), but the largest general proportion of animal attacks on people was from dogs - 838,635 attacks (77.7\%). Geographically, the highest frequency of attacks by domestic carnivores was observed in the east of Ukraine, that of attacks by foxes in the central and western oblasts. The majority (71.5\%) of victims of attack by dogs and cats were victims of animals that had owners, the share of attacks from stray cats and dogs was $27.4 \%$.

The risks to humans of infection with the rabies virus transmitted by pets are increasing due to their owners' failure to comply with the rules of keeping animals, increase in the population of stray domestic carnivores, the low level of vaccination of pets, low-level of public awareness and the absence of comprehensive expert assessment. Ensuring the prevention of rabies in humans requires the availability of PEP for the population, the availability of vaccines against rabies and RIG, the readiness of medical staff, high efficacy of rabies drugs, and the need to closely link the two sectors of human and animal health based on a "One Health" approach.

In conclusion, our results confirm he high risk of infection by the rabies virus from wild animals and also from domestic animals, which is a matter of concern to European countries due to the distribution of unvaccinated domestic carnivores and the possibility of transmission of rabies to humans in cases of tourism because most EU countries eliminated rabies in humans many years ago.

The authors would like to acknowledge the United States Defense Threat Reduction Agency, SAFOSO AG, Switzerland and Ukraine Biological Threat Reduction Program for their assistance and financial support in the preparation of this paper.

The authors declare no competing interests.

\section{References}

Acharya, K. P., Acharya, N., Phuyal, S., Upadhyaya, M., \& Lasee, S. (2020). Onehealth approach: A best possible way to control rabies. One Health, 10, 100161. Anderson, A., Kotze, J., Shwiff, S. A., Hatch, B., Slootmaker, C., Conan, A., Knobel, D., \& Nel, L. H. (2019). A bioeconomic model for the optimization of local canine rabies control. PLoS Neglected Tropical Diseases, 13(5), e0007377.

Antonova L, Makovska, I, \& Krupinina, T. (2021). Istoriya bor'by s beshenstvom v Ukraine so vremen Pastera do nashih dnej [The history of the elimination of rabies in Ukraine from the time of Pasteur to the present day]. Actual Infectiology, 9(1), 1-12 (in Russian).

Baghi, H. B., Alinezhad, F., Kuzmin, I., \& Rupprecht, C. E. (2018). A perspective on rabies in the Middle East-beyond neglect. Veterinary Science, 5(3), 67.

Baker, L., Matthiopoulos, J., Müller, T., Freuling, C., \& Hampson, K. (2020). Local rabies transmission and regional spatial coupling in European foxes. PLoS One, 15(5), e0220592.

Botvinkin, A., \& Kosenko, M. (2004). Rabies in the European parts of Russia, Belarus and Ukraine. In: King, A. A., Fooks, A. R., Aubert, M., \& Wandeler, A. I. Historical perspective of rabies in Europe and the Mediterranean Basin. World Organization for Animal Health, Paris. Pp. 47-63. 
Brookes, V. J., Dürr, S., \& Ward, M. P. (2019). Rabies-induced behavioural changes are key to rabies persistence in dog populations: Investigation using a networkbased model. PLoS Neglected Tropical Diseases, 13(9), e0007739.

Calvelage, S., Smreczak, M., Orłowska, A., Freuling, C. M., Müller, T., Fehlner-Gardiner, C., Nadin-Davis, S., Höper, D., \& Trębas, P. (2020). Population and variant-based genome analyses ofviruses from vaccine-derived rabies cases demonstrate product specific clusters and unique patterns. Viruses, 12(1), 115.

Chikanya, E., Macherera, M., \& Maviza, A. (2021). An assessment of risk factors for contracting rabies among dog bite cases recorded in Ward 30, Murewa district, Zimbabwe. PLoS Neglected Tropical Disiases, 15(3), e0009305.

Cliquet, F., Picard-Meyer, E., \& Robardet, E. (2014). Rabies in Europe: What are the risks? Expert Review of Anti-Infective Therapy, 12(8), 905-908.

Drozhzhe, Z. (2015). Dynamika poshyrennia skazu v Ukrajini ta Evropi u 2003 2013 rokakh [Dynamics of the spread of rabies in Ukraine and Europe in 2003 2013]. Veterinary Biotechnology, 26, 70-76 (in Ukrainian).

Fahrion, A. S., Taylor, L. H., Torres, G., Müller, T., Dürr, S., Knopf, L., de Balogh, K. Nel, L. H., Gordoncillo, M. J., \& Abela-Ridder, B. (2017). The road to dog rabies control and elimination - what keeps us from moving faster? Frontiers in Public Health, 5, 103.

Fisher, C., Streicker, D., \& Schnell, M. (2018). The spread and evolution of rabies virus: Conquering new frontiers. Nature Reviews Microbiology, 16(4), 241-255.

Fooks, A. R., Cliquet, F., Finke, S., Freuling, C., Hemachudha, T., Mani, R. S., Müller, T., Nadin-Davis, S., Picard-Meyer, E., Wilde, H., \& Banyard, A. C. (2017). Rabies. Nature Reviews Disease Primers, 3, 17091

Franka, R., \& Wallace, R. (2018). Rabies diagnosis and surveillance in animals in the era of rabies elimination. Revue Scientifique et Technique de l'OIE, 37(2), 359-370.

Freuling, C., Hampson, K., Selhorst, T., Schröder, R., Meslin, F., Mettenleiter, T., \& Müller, T. (2013). The elimination of fox rabies from Europe: Determinants of success and lessons for the future. Philosophical Transactions of the Royal Society: Biological Sciences, 368, 20120142.

Gholami, A., \& Alamdary, A. (2020). The world rabies day 2020: Collaborate and vaccinate. Iranian Biomedical Journal, 24(5), 264-268.

Grigoryan, G. V., \& Metlin, A. Y. (2016). Global financial crisis as a challenge for prevention of human rabies in the former soviet republics. Austin Virology and Retro Virology, 3(1), 1016

Hampson, K., Coudeville, L., Lembo, T., Sambo, M., Kieffer, A., Attlan, M., Barrat, J., Blanton, J. D., Briggs, D. J., Cleaveland, S., Costa, P., Freuling, C. M., Hiby, E., Knopf, L., Leanes, F., Meslin, F. X., Metlin, A., Miranda, M. E., Müller, T., \& Dushoff, J. (2015). Estimating the global burden of endemic canine rabies. PLoS Neglected Tropical Diseases, 9(5), e0003786.

Klein, A., Fahrion, A., Finke, S., Eyngor, M., Novak, S., Yakobson, B., Ngoepe, E., Phahladira, B., Sabeta, C., De Benedictis, P., Gourlaouen, M., Orciari, L. A., Yager, P. A., Gigante, C. M., Knowles, M. K., Fehlner-Gardiner, C., Servat, A. Cliquet, F., Marston, D., \& Freuling, C. M. (2020). Further evidence of inadequate quality in lateral flow devices commercially offered for the diagnosis of rabies. Tropical Medicine and Infectious Disease, 5(1), 13.

Kornienko, L. E., Moroz, O. A., Mezhensky, A. O., Skorokhod, S. V., Datsenko, R. A., Karpulenko, M. S., Polupan, I. M., Dzyuba, Y. M., Nedosekov, V. V., Makovska, I. F., Hibaliuk, Y. O., Sonko, M. P., Tsarenko, T. M., \& Pishchanskyi, O. V. (2019). Epizootolohichni ta epidemiolohichni aspekty skazu v Ukrayini za period 1999-2018 rr. [Epizootological and epidemiological aspects for rabies in Ukraine for the period from 1999 to 2018]. Veterinary Science, Technologies of Animal Husbandry and Nature Management, 3, 90-109 (in Ukrainian).

Makovska, I. (2020a). Modelling the spread of rabies in Ukraine. Ukrainian Joumal of Veterinary Sciences, 11(3), 33-45.

Makovska, I. (2020b). Novitni pidkhody do analizu epizootychnoi sytuatsii zi skazu $\mathrm{v}$ Ukraini [New approaches to the analysis on epizootic situation of rabies in Ukraine]. The Animal Biology, 22(1), 31-35 (in Ukrainian).
Makovska, I., Nedosekov, V., Kornienko, L., Novokhatny, Y., Nebogatkin, I., \& Yustyniuk, V. (2020). Retrospective study of rabies epidemiology in Ukraine (1950-2019). Theoretical and Applied Veterinary Medicine, 8(1), 36-49.

Makovska, I., Nedosekov, V., Polupan, I., \& Latmanizova, T. (2018). Analiz trendu poshyrennnia skazu kotiv v Ukrajini [Distribution trend rabies in cats in Ukraine]. Scientific Messenger of LNU of Veterinary Medicine and Biotechnologies, 20(92), 18-23 (in Ukrainian).

Meyerhoff, P., Manekeller, S., Saleh, N., Boesecke, C., Schlabe, S., Wasmuth, J., Bremen, K., Eis-Hübinger, A. M., von Fischer-Treuenfeld, J., Menting, T., Rockstroh, J., \& Schwarze-Zander, C. (2021). Rabies post-exposureprophylaxis in Germany - what are the challenges? Epidemiology and Infection, 506, 1-10.

Mogilevsky, B. Y. (1997). Praktycheskaia rabyolohyia [Practical rabiesology]. Naddnipryanochka, Kherson (in Russian).

Müller, T., \& Freuling, C. M. (2020). Rabies in terrestrial animals. In: Fooks, A. R. \& Jackson, A. C. (Eds.). Rabies. Fourth Edition. Academic Press, Elsevier, Greifswald-Insel Riems. Pp. 195-230.

Picard-Meyer, E., Robardet, E., Moroz, D., Trotsenko, Z., Drozhzhe, Z., Biarnais, M., Solodchuk, V., Smreczak, M., \& Cliquet, F. (2012). Molecular epidemiology of rabies in Ukraine. Archives of Virology, 157(9), 1689-1698.

Polupan, I. M., Nedosekov, V. V., Stepanova, T. V., Rudoi, O. V., Parshikova, A. V., \& Drozdova, E. I. (2021). Molecular characteristics isolates of rabies virus isolated from humans in Ukraine. IOP Conference Series: Earth and Environmental Science, 677, 042025.

Regea, G. (2017). Review on economic importance's of rabies in developing countries and its controls. Archives of Preventive Medicine, 2(1), 15-21.

Robardet, E., Bosnjak, D., Englund, L., Demetriou, P., Martin, P., \& Cliquet, F. (2019). Zero endemic cases of wildlife rabies (Classical Rabies Virus, RABV) in the European Union by 2020: An achievable goal. Tropical Medicine and Infectious Disease, 4(4), 124

Roebling, A. D., Johnson, D., Blanton, J. D., Levin, M., Slate, D., Fenwick, G., \& Rupprecht, C. E. (2014). Rabies prevention and management of cats in the context of trap-neuter-vaccinate-release programmes. Zoonoses and Public Health, 61(4), 290-296.

Rupprecht, C. E., \& Salahuddin, N. (2019). Current status of human rabies prevention: Remaining barriers to global biologics accessibility and disease elimination. Expert Review Vaccines, 18(6), 629-640.

Shwiff, S., Hampson, K., \& Anderson, A. (2013). Potential economic benefits of eliminating canine rabies. Antiviral Research, 98(2), 352-356.

Taylor, E., Del Rio Vilas, V., Scott, T., Coetzer, A., Prada, J. M., Alireza, G., Alqadi, N. A., Berry, A., Bazzal, B., Barkia, A., Davlyatov, F., Farahtaj, F., Harabech, K., Imnadze, P., Mahiout, F., Majeed, M. I., Nedosekov, V., Nel, L., Rich, H., \& Horton, D. (2021). Rabies in the Middle East, Eastern Europe, Central Asia North Africa: Building. Journal of Infection and Public Health, in press.

Wallace, R., Undurraga, E., Blanton, J., Cleaton, J., \& Franka, R. (2017). Elimination of dog-mediated human rabies deaths by 2030: Needs assessment and altematives for progress based on dog vaccination. Frontiers in Veterinary Science, 4, 9.

Warembourg, C., Wera, E., Odoch, T., Bulu, P. M., Berger-González, M., Alvarez, D., Abakar, M. F., Maximiano Sousa, F., Cunha Silva, L., Alobo, G., Bal, V. D., López Hernandez, A. L., Madaye, E., Meo, M. S., Naminou, A., Roquel, P., Hartnack, S., \& Dürr, S. (2021). Comparative study of free-roaming domestic dog management and roaming behavior across four countries: Chad, Guatemala, Indonesia, and Uganda. Frontiers in Veterinary Science, 8, 617900.

World Health Organization (2018). WHO expert consultation on rabies. WHO Press World Health Organization, Geneva. Pp. 3-15.

Yoder, J., Younce, E., Lankester, F., \& Palmer, G. H. (2019). Healthcare demand in response to rabies elimination campaigns in Latin America. PLoS Neglected Tropical Diseases, 13(9), e0007630. 